AL IBTIDA: JURNAL PENDIDIKAN GURU MI (2019) Vol 6 (1): 134-143

DOI: http://dx.doi.org/ 10.24235/al.ibtida.snj.v6i1.3640

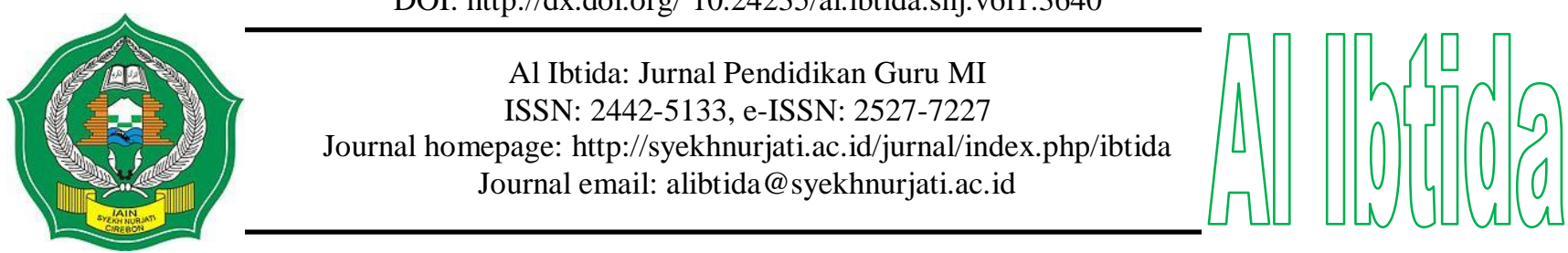

\title{
The Influence of Television Watching Intensity on the Students' Learning Interest
}

\author{
Patimah* \\ *Department of Madrasah Ibtidaiyah Teacher Education, Faculty of Tarbiyah and Teacher Training, \\ IAIN Syekh Nurjati Cirebon \\ Email: patimahwardono@gmail.com \\ Yaya Kiswaya** \\ **Department of Madrasah Ibtidaiyah Teacher Education, Faculty of Tarbiyah and Teacher Training, \\ IAIN Syekh Nurjati Cirebon \\ Email: yaya29kiswaya@gmail.com
}

Received: January $16^{\text {th }}, 2019$. Accepted: June $24^{\text {th }}, 2019$. Published: June $30^{\text {th }}, 2019$.

\begin{abstract}
This research is based on the low of students' interest in learning. This is because they spend more time to watch television than to learn. This study aims to examine the effect of TV watching intensity on the students' learning interest. This study uses quantitative methods with correlational design. Data are collected through questionnaire and observation. Meanwhile, the data analysis technique used was the regression test analysis. The results of the study show that the intensity of TV watching is $78 \%$ with high criterion and student learning interest is $89 \%$ with a high criterion. Based on the results of the regression test, it was found that the significant value is 0,000 . Because the significant value is smaller than 0.05 and t count (4.817) is bigger than t table (2.052), Ho is rejected, meaning that the intensity of TV watching shows has a significant effect on the students' learning interest. Therefore, parents should be able to limit their time watching television to their children so that children's learning interest does not decrease.
\end{abstract}

Keywords: students' learning interest, television, watching intensity.

\begin{abstract}
Abstrak
Penelitian ini dilatar belakangi oleh rendahnya minat belajar siswa. Hal ini karena mereka lebih banyak menghabiskan waktu untuk menonton televisi dibandingkan dengan belajar. Penelitian ini bertujuan untuk meneliti tentang pengaruh intensitas menonton televisi terhadap minat belajar siswa. Penelitian ini menggunakan metode kuantitatif dengan desain korelasional. Teknik pengumpulan data menggunakan angket dan observasi. Sementara itu, teknik analisis data yang digunakan adalah analisis uji regresi. Hasil penelitian ini menunjukkan bahwa intensitas menonton tayangan televisi sebesar $78 \%$ dengan kriteria tinggi dan minat belajar siswa sebesar 89\% dengan kriteria tinggi. Berdasarkan hasil uji regresi diperoleh bahwa signifikansinya sebesar 0,000 . Karena nilai signifikansinya lebih kecil dari 0,05 dan $t$ hitung $(4,817)$ lebih besar dari t tabel $(2,052)$ maka Ho ditolak, artinya bahwa intensitas menonton tayangan televisi berpengaruh signifikan terhadap minat belajar
\end{abstract}


siswa. Oleh karena itu, hendaknya orang tua dapat membatasi waktu menonton televisi kepada anak-anaknya agar minat belajar anak tidak menurun.

Kata kunci: intensitas menonton, minat belajar siswa, televisi.

\section{INTRODUCTION}

Nowadays, almost every family in Indonesia has television as a family entertainment media that can provide entertainment for up to 24 hours. The survey from Nielsen.com (2018) states that the level of television viewing in Indonesia is high, of which $97 \%$ of the Indonesian population is $10-19$ years old, $96 \%$ of the population is $20-34$ years old, $97 \%$ of the population is 35-49 years old, and 95\% of baby boomers (ages 50-64 years) love watching television. The Nielsen study also states that the average Indonesian population spends 5 hours watching television. Obviously this indicates the high use of television at home.

Parents provide television at home even in rooms so that children feel at home. In fact, it is not uncommon for parents to add satellite television programs or DVDs at their homes so that children are more comfortable at home. But parents don't realize that this can cause children to become addicted to watching television. Children who are already addicted to television tend to be lazy to learn (Rohani, 2015), lack socialization and passivity (Arta, 2016). Interaction with friends and family is replaced by watching treats on the glass screen. Likewise the opportunity to develop interest in learning will be lost, because his interest is only directed at television. This is certainly not good for the development of a child's learning interest (Arta, 2016).

Zaini (2016) suggests that television is an electronic system for transmitting moving images and sound to receivers. According to Irfan, Mesran, \& Siregar (2017) television is a wellknown telecommunications media that is used to transmit and receive broadcast images, whe ther monochrome (black and white) or color, usually equipped with sound. Whereas according to Tondowidjojo in (Azmi, 2014) television is part of mass media which means the process of delivering news through technical means for the public interest and unknown large groups where the recipient can answer the news directly.

From the above understanding, it can be concluded that television media has privileges as a means of not only providing information, but also entertainment and education, which can be simultaneously heard and seen by the audience. Television can be an effective communication medium for children if the delivery can be understood by children, although later the reaction that arises is different from the message delivered. Psychologically we can say that everyone perceives stimulation according to his personal characteristics (Natadjaja, 2002).

Watching television shows has a detrimental effect on brain development, because television can provide excessive stimulation of the right brain that functions to protest views and reduce stimulation in the left brain responsible for language and processing of printed material. 
Watching television also shows a negative correlation with students' interest in learning. Television with various broadcasts and entertainment is indeed enjoyed by the public. But if it is not used wisely by students, then what is watched will damage the morale and behavior of students. Spending time in silence in front of a television screen means that students are lazy to learn and reduce students' interest in learning (Ma'arifah, Yusdin \& Imran, 2016).

From the results of interviews conducted with Ms. Hj. Elis, S.Pd.I. as the teacher of class IV B in Madrasah Ibtidaiyah (MI) Al-Washliyah, Regency of Cirebon, information was obtained that most students were less interested in attending lessons from the beginning to the end of the lesson. The results of observations made by researchers during the learning process took place also showed that students were less happy, less interested, less attention and less directly involved in the learning process. So when a teacher gives homework to students, there are still many students who don't do it.

Research that is quite relevant has been carried out by Agustina (2016) who conducted research at MIN 2 Model Samarinda. The results show that students at the school are mostly sleepy in the morning. This is because in the afternoon they mostly play and at night they watch television late at night. So that when students are in school to take lessons, they are not interested in learning and there is no interest in learning. To make students happy to learn, want to pay attention and be directly involved in the learning process, students need passion and strong learning interest. Therefore, the role of a teacher is very important in fostering students' interest in learning. High interest in learning will have an impact on maximum learning outcomes, because interest is one of the biggest factors in learning (Lestari, 2013; Putri \& Isnani, 2015).

The interest in learning is feeling happy, motivated, and caring for businesses to get knowledge (Astuti, 2015; Nurhasanah \& Sobandi, 2016; Firmansyah, 2015). Interest is a psychological aspect of a person to pay high attention to certain activities and encourage the person concerned to carry out these activities in an effort to obtain something. The size of the interest that is owned will greatly influence the results to be obtained. An activity will be carried out or not depends on someone's interest in the activity. Here it appears that interest is a strong motivator for carrying out an activity, including learning.

In line with the results of research conducted by (Nurhasanah \& Sobandi, 2016; Rusmiati, 2017) it was found that interest in learning had a significant influence on learning outcomes. To get good learning outcomes, increasing interest in learning can be the solution. So that it can be concluded that the better the interest in learning students will have an impact on student learning outcomes that are getting better too. Meanwhile, research conducted by Putri \& Isnani (2015) shows that interest is the dominant variable in influencing learning outcomes. Furthermore, the results of his research are Ma'arifah, Yusdin \& Imran (2015); Santoso (2017) also shows that 
watching television broadcasts can have a negative impact. One of them is the decline in student learning achievement. This study aims to examine the effect of the intensity of watching television on student learning interests.

\section{METHODS}

The method used in this study is a quantitative method, namely the approach in the research process, hypothesis, down to the field, data analysis and data conclusions up to writing using measurement, calculation, formula and numerical data certainty aspects (Musianto, 2002). This study uses a correlational research design. The population in this study were all class IV B MI Al-Washliyah Perbutulan Cirebon Regency which amounted to 30 students. The sampling technique is saturated sampling, where all populations are sampled.

Data collection techniques used in this study were questionnaires and observations. Questionnaire was used to find out how much the intensity of class IV B MI Al-Washliyah students in watching television shows. The questionnaire consisted of 16 statement items with 8 positive questionnaire items and 8 negative questionnaire items with SS answer choices (Strongly Agree), S (Agree), TS (Disagree), STS (Strongly Disagree). Before conducting questionnaires, researchers provide direction on how to fill out the questionnaire sheet to students. Meanwhile, observation is used to determine student interest in the learning process in the classroom. This observation sheet uses the checklist list.

The data analysis technique used is the questionnaire data test and simple regression test which includes ANOVA test, regression coefficient test, and determination test. ANOVA test is used to see whether there is an influence between the intensity of watching television on student learning interest, regression coefficient test is used to see how the regression equation and determination test are used to see how much influence the intensity of watching television on student learning interests.

\section{RESULTS AND DISCUSSION}

\section{Students' Intensity in Watching Televison}

The results of the student questionnaire regarding the intensity of the students in watching television shows are as shown in table 1 below:

Table 1. Recapitulation of the Questionnaire Data

\begin{tabular}{llllll}
\hline Scale & $\begin{array}{l}\text { Strongly } \\
\text { Agree }\end{array}$ & Agree & Disagree & $\begin{array}{l}\text { Strongly } \\
\text { Disagree }\end{array}$ & Total \\
\hline Positive Score (+) & 364 & 330 & 62 & 8 & 764 \\
\hline Negative Score (-) & 4 & 80 & 414 & 232 & 730 \\
\hline \multicolumn{7}{c}{ Total Score } \\
\hline
\end{tabular}


Based on table 1, it can be seen that the number of positive and negative revelation scores obtained from 30 students with 16 items is 368 scores for the strongly agree category, 410 scores for the agreed category, 476 scores for the dissagree category, and 240 scores for the strongly disagree category. Thus, the total positive and negative statement scores were 1,494 scores. The ideal score for this questionnaire is 16 statement items x 30 students x 4 (maximum score for each item $)=1,920$. So that the percentage of the achievement of the questionnaire score intensity of students watching television shows is as big as:

$$
\frac{1,494}{1,920} \times 100 \%=78 \%
$$

The $78 \%$ percentage belongs to the high category, because it is in the percentage range of $75 \%-85 \%$. So, it can be concluded that the intensity of students watching television shows is high.

\section{Students' Learning Interest}

The observational data of students' interest in learning can be presented in the following table 2:

Table 2. Observation Results Data of Students' Learning Interest

\begin{tabular}{ccccc}
\hline Students & Total score & Average score & Prosentase & Information \\
\hline 30 & 322 & 10,7 & $89 \%$ & Tinggi \\
\hline
\end{tabular}

Table 2 above shows that of the 30 students observed, a total score of 322 scores was obtained, with an average score of 10.7. The ideal score for this observation is 360 scores. So that the percentage of achievement of the results of observations of student learning interest is equal to:

$$
\frac{322}{360} \times 100 \%=89 \%
$$

The percentage of $89 \%$ belongs to the high category, because it is in the percentage range of $75 \%-85 \%$. So it can be concluded that students' interest in learning is high.

\section{The Influence of Television Watching Intensity on the Students' Learning Interest}

To determine the effect/influence of the intensity of watching television shows on students' interest in learning, researchers used a simple regression test analysis. This simple regression test consists of ANOVA test, regression coefficient test and determination test. The results of a simple regression test analysis can be presented in the following table. 
Table 3. ANOVA ${ }^{\text {a }}$ Test

\begin{tabular}{llllll}
\hline Model & Sum of Squares & Df & Mean Square & F & Sig. \\
\hline Regression & 1677.155 & 1 & 1677.155 & 23.199 & $.000^{\mathrm{b}}$ \\
Residual & 2024.211 & 28 & 72.293 & & \\
\hline Total & 3701.367 & 29 & & & \\
\hline
\end{tabular}

a. Dependent Variable: Learning Interest

b. Predictors: (Constant), TV Watching Intensity

The ANOVA test results in table 3 show that the calculated $F$ value is 23,841 with a significance level of 0,000 . This value is then compared with $\mathrm{F}$ table which is calculated at the numerator free degree (numerator $\mathrm{df}$ ) of 1 and the denominator's free degree (df denominator) is 28 at the level of 0.05 whose value is 4.20 . It seems very clear that the calculated $F$ value (23.841) is greater than F table (4.20). So it can be concluded that the intensity of watching television shows a positive effect on students' learning interest. To find out the linear regression equation, can be seen in table 4 below:

Tabel 4. Coefficients of Regression Test ${ }^{\mathbf{a}}$

\begin{tabular}{|c|c|c|c|c|c|}
\hline \multirow[t]{2}{*}{ Model } & \multicolumn{2}{|c|}{$\begin{array}{l}\text { Unstandardized } \\
\text { Coefficients }\end{array}$} & \multirow{2}{*}{$\begin{array}{l}\text { Standardized } \\
\text { Coefficients } \\
\text { Beta } \\
\end{array}$} & \multirow[t]{2}{*}{$\mathbf{T}$} & \multirow[t]{2}{*}{ Sig. } \\
\hline & B & Std. Error & & & \\
\hline (Constant) & -23.324 & 13.882 & & 1.680 & .104 \\
\hline $\begin{array}{l}\text { TV Watching } \\
\text { Intensity }\end{array}$ & .865 & .180 & .673 & 4.817 & .000 \\
\hline
\end{tabular}

In table 4 , the regression coefficient test above shows that the constant value is $-23,324$ and the value of student intensity in watching television shows is 0.865 . From this information, the regression equation can be obtained as follows:

$$
Y=-23,324+0,865 X
$$

It is known that the constant value is $-23,324$. This states that if there is no increase in the value or score of the intensity variable watching television shows, the variable interest in learning is equal to $-23,324$. Meanwhile, the value of the intensity of television viewing is 0.865 . This states that every increase in the score of the intensity variable watching television shows will be able to increase the increase in students' interest in learning interest. To see how much the intensity of watching television shows the influence of students' interest in learning can be presented in table 5 below: 
Table 5. Determinasi Test / R-Square Test

\begin{tabular}{|c|c|c|c|c|}
\hline Model & $\mathbf{R}$ & R Square & $\begin{array}{l}\text { Adjusted R } \\
\text { Square }\end{array}$ & $\begin{array}{l}\text { Std. Error of the } \\
\text { Estimate }\end{array}$ \\
\hline 1 & $.673^{\mathrm{a}}$ & .453 & .434 & 8.503 \\
\hline
\end{tabular}

In table 5 , the determination test above shows that $\mathrm{R}$ Square is 0.453 (square of the correlation coefficient 0.673 ). R Square is called the determinant coefficient which in this case is 45.3\%. From this value can be interpreted that $45.3 \%$ interest in learning students of Class IV MI Al-Washliyah Cirebon Regency is influenced by the intensity of watching television shows, while $54.7 \%$ are influenced by other factors.

From the results of the above research, it is known that the intensity of watching television shows has a positive effect on students' interest in learning. This is because according to Owens, Maxim, McGuinn, Nobile, Msall, \& Alario (1999) in his research revealed that the intensity of watching television shows causes sleep disturbances in students, both sleep deprivation and things that make a child's sleep not sound, such as resistance to sleep and anxiety when sleeping. With the presence of sleep disorders and reduced sleep time, of course this will disrupt the learning activities the next day.

In addition to reduced sleep time and sleep disturbances, the intensity of watching television also affects the discipline of children in obeying study time. Pitriawanti (2010) in his research suggests that students who have high intensity in watching television have low discipline in obeying study time. This also certainly shows that students' interest is low in learning when the intensity of watching television is high. Low discipline also signifies the low interest of students in learning.

In addition to the low level of discipline, the intensity of watching television also causes various problems, one of which is a decrease in school performance. Bar-On (2001) in his research suggested that various negative effects of television such as violent or aggressive behavior, drug use, sexual activity, obesity, poor body image and decreased school performance. Therefore the intensity of watching television must be given more attention by parents.

We often find that children spend more time watching television than learning. Data from the Indonesian Child Welfare Foundation in (Arta, 2016) states that children spend time watching television for 30-25 hours a week. This can be interpreted that children in the city of Medan according to the results of the AGB Nielsen research (Arta, 2016) spent 3 hours a day and during the holiday time watching increased to 4-6 hours a day. The rise of television viewing activities because the shows broadcast on television are very varied and one of them is a cartoon 
film that is very popular and able to attract the attention of children so as to make children addicted.

This is similar to what was stated by Ridwan \& Prasetya (2015) that the influence of media on children is getting bigger, technology is increasingly sophisticated, and the intensity is getting higher. Though parents do not have time to pay attention, accompany, and supervise children. Children spend more time watching television than doing other things. So watching television becomes a mandatory habit every day. Watching cartoon shows is the habit of children every day. However, children's habits in watching cartoons must be considered and must be given a limit, so that parents can find out good cartoon shows for children to watch. Another thing that needs to be done by parents is to give children the limits of watching cartoons, so that later a child will not be stunned to get used to watching cartoons.

In the learning process, a teacher must be able to know the interest in learning or to know the extent of students' interest in learning from the beginning to the end of learning. Because according to Dalyono (2009) interest is a feeling of preferring and feeling interested in a thing or activity, without anyone telling. Meanwhile, learning is a series of bodily souls to obtain a change in behavior as a result of individual experiences in interaction with their environment which involves cognitive, affective and psychomotor.

Thus, it can be concluded that interest in learning is the tendency of individuals to have pleasure without any coercion so that it can cause changes in knowledge, skills, and behavior. There are three factors that can increase student learning interest, namely 1) internal selfmotivation factors, 2) social motivation factors, and 3) emotional factors (Simbolon, 2013). These three things will not be fulfilled if the process is disturbed by other activities such as watching television.

In a habit carried out by someone, later it will surely have a positive or negative impact or effect on what he has done. No exception to what has become the habit of a student or student when they are at home. The habit of watching television shows has become commonplace and has become a routine for students when after school or during school holidays. Finally, from watching television, a child will feel lazy to learn and no interest at all to learn.

\section{CONCLUSION}

Based on the description of the results of the research and discussion it can be concluded that the intensity of watching television shows has a positive effect on the learning interest of fourth grade students of MI Al-Washliyah in the Regency of Cirebon in the amount of $45.3 \%$. While the rest is influenced by other factors. Therefore, the intensity of watching television must be given more attention by parents. Because the intensity of watching television is high will have 
an impact on the low interest in learning students. And low student learning interest will also have an impact on the low student learning outcomes.

\section{REFERENCES}

Agustina, D. (2016). Pengaruh Intensitas Menonton Televisi terhadap Kedisiplinan Anak dalam Membagi Waktu Belajar di MIN 2 Model Samarinda. Ilmu Komunikasi, 4(3), 305-319.

Arta, D. J. (2016). Pengaruh Pemilihan Tayangan Televisi terhadap Perkembangan Sosial Anak. Edu Tech, 2(1), 18-24.

Astuti. (2015). Pengaruh Kemampuan Awal dan Minat Belajar terhadap Prestasi Belajar Fisika. Jurnal formatif, 5(1), 68-75.

Azmi, N. (2014). Dampak Media Televisi terhadap Perilaku Sosial Anak. Scientiae Educatia, $3(2), 11-28$.

Bar-on, M. E. (2001). Childrens Adolenscents and Television. Pedriatics, 107(2), 423-426.

Dalyono, M. (2009). Psikologi Pendidikan. Jakarta: Rineka Cipta.

Firmansyah, D. (2015). Pengaruh Strategi Pembelajaran dan Minat Belajar terhadap Hasil Belajar Matematika. Jurnal Pendidikan Unsika, 3(1), 34-44.

Irfan, M., Mesran, M., \& Siregar, D. (2017). Rancangan Pendukung Keputusan Pemilihan Televisi Berlangganan Menerapkan Metode Analytical Hierarchy Process (AHP). Jurnal Media Informatika Budidarm, 1(2), 42-48.

Lestari, I. (2013). Pengaruh Waktu Belajar dan Minat Belajar terhadap Hasil Belajar Matematika. Jurnal Formatif, 3(2), 115-125.

Ma'arifah, Yusdin \& Imran. (2015). Dampak Menonton Siaran Televisi terhadap Prestasi Belajar Siswa pada Mata Pelajaran Pkn di Kelas IV SD Inpres 2 Tada Kecamatan Tinombo Selatan. Kreatif Online Taduloko, 1(1), 89-102.

Musianto. (2002). Perbedaan Pendekatan Kuantitatif dengan Pendekatan Kualitatif dalam Metode Penelitian. Jurnal Manajemen dan Kewirausahaan, 4(2), 123-136.

Natadjaja, L. (2002). Pengaruh Iklan untuk Anak Dibandingkan dengan Film Kartun Televisi terhadap Afektif Anak. Nirmana, 4(1), 73-84.

Nielsen.(2018). Promosi Digital Lebih Akurat dengan Nielsen Digital Adrating. Tersedia: https://www.nielsen.com/id/en/press-room/2018/promosi-digital-lebih-akurat-dengannielsen-digital-adratings.html.

Nurhasanah, S. \& Sobandi, A. (2016). Minat belajar sebagai determinan hasil belajar siswa. Manper: Jurnal Pendidikan Manajemen Perkantoran, 1(1), 135-142.

Owens, J., Maxim, R., McGuinn, M., Nobile, C., Msall, M., \& Alario, A. (1999). Televisionviewing habits and sleep disturbance in school children. Pediatrics, 104(3), e27.

Pitriawanti, A. (2010). Pengaruh Intensitas Menonton Televisi dan Komunikasi Orang Tua terhadap Kedisiplinan Anak dalam Menaati Waktu Belajar. Tesis. Universitas Diponegoro. 
Putri, D. T. N., \& Isnani, G. (2015). Pengaruh minat dan motivasi terhadap hasil belajar pada mata pelajaran pengantar administrasi perkantoran. JPBM (Jurnal Pendidikan Bisnis dan Manajemen), 1(2), 118-124.

Ridwan, A. \& Prasetya, T. (2015). Dampak Sering Menonton Televisi pada Usia Sekolah. Akp, $6(1), 9-20$.

Rohani. (2015). Pengaruh Televisi (TV) terhadap Aspek-Aspek Perkembangan Anak Usia 3-4 Tahun. Jurnal Pendidikan Anak, 4(2), 631-639.

Rusmiati. (2017). Pengatuh Minat Belajar Terhadap Prestasi Belajar Bidang Studi Ekonomi Siswa Ma Al Fattah Sumbermulyo. Utility: Jurnal Ilmiah Pendidikan dan Ekonomi, 1(1), 21-36.

Santoso, T. (2017). Pengaruh Intensitas Menonton Tayangan Sinetron Anak Jalanan Pada Perilaku Intensitas Siswa SMP. Jurnal Kajian Media, 1(2), 122-131.

Simbolon. (2013). Faktor-Faktor yang Mempengaruhi Minat Belajar Peserta Didik. Elementary School Journal PGSD FIP Unimed, 1(2), 14-19.

Zaini, A. (2016). Dakwah Melalui Televisi. At-Tabsyir. Jurnal Komunikasi Penyiaran Islam, $3(1), 1-20$. 